\title{
Evaluating the Waste Prevention Potential of a Multi- versus Single-Use Surgical Stapler
}

\author{
Markus Meissner' \\ Sabrina Lichtnegger' \\ Scott Gibson ${ }^{2}$ \\ Rhodri Saunders $\left(\mathbb{D}^{2}\right.$ \\ 'Austrian Institute of Ecology, Vienna, \\ Austria; ${ }^{2}$ Coreva Scientific GmbH \& Co \\ KG, Koenigswinter, Germany
}

Correspondence: Rhodri Saunders

Coreva Scientific GmbH \& Co KG,

Koenigswinter, Germany

Tel +49 22237818010

Fax +4976176999421

Email rhodri@coreva-scientific.com
Purpose: Within the hospital, surgery is recognized as a resource-intensive activity that disproportionately generates large volumes of healthcare waste. Single-use, disposable medical supplies contribute substantially to this problem, and more broadly to the depletion of scarce resources. Given that many surgical procedures utilize surgical stapling techniques, this study uses surgical stapling systems as functional units for evaluating the waste prevention potential of switching from single-use systems (SUSs) to multi-use systems (MUSs).

Materials and Methods: Two frequently used surgical stapling systems, Ethicon's SUS: ECHELON FLEX ${ }^{\mathrm{TM}}$ and Medtronic's MUS: Signia ${ }^{\mathrm{TM}}$ Stapling Technology, were mechanically deconstructed to their individual raw material components to calculate the composition of each system. Total waste as well as extended resource use (the total material requirement [TMR]) were then calculated for three different surgical procedures; laparoscopic sleeve gastrectomy, laparoscopic gastric bypass, and video-assisted thoracoscopic (VATS) lobectomy. The differences in outcomes for SUSs versus MUSs were then calculated.

Results: For each surgical procedure considered, switching from a SUS to a MUS led to a reduction in total waste accumulated per procedure and TMR. Reductions in waste were 40\% (sleeve gastrectomy), 70\% (gastric bypass), and 62\% (VATS lobectomy). The TMR reductions were higher, at 92\% (sleeve gastrectomy), 96\% (gastric bypass), and 95\% (VATS lobectomy). Both waste and TMR reduction were realized with the MUS system as long as the reusable parts were used more than four times. This was true for all analyzed surgical procedures.

Conclusion: Switching from a SUS to MUS facilitates a reduction in total surgical waste and TMR for sleeve gastrectomy, gastric bypass, and VATS lobectomy surgical procedures. Keywords: circular economy, reuse, resource efficiency, hospital costs, operating room, healthcare economics

\section{Introduction}

The environmental threats we currently face are multi-faceted, far-reaching, and severe, with the climate-related consequences arising from healthcare activity increasingly identified as unsustainable and a cause for concern. ${ }^{1-3}$ One such concern pertains to excess resource consumption and waste production. It is estimated that United States (US) hospitals generate $8.4 \mathrm{~kg}$ waste per patient per day, whereas United Kingdom (UK) hospitals produce on average $3.3 \mathrm{~kg}$ of waste per patient per day. ${ }^{4}$ At the national level, US hospitals reportedly produce 5.9 megatons of waste each year, ${ }^{5}$ whilst the UK National Health Service (NHS), between 2016 and 2017, disposed of 538,600 tons of waste, costing £115 million. ${ }^{5}$ Confronting excess resource consumption and waste, and recognizing the value 
from raw materials that is lost when manufactured products are used once and then discarded should therefore be prioritized in order to encourage more sustainable resource use practices in the healthcare sector. ${ }^{6}$

Since the start of the 20th century, the demand for material resources has increased, resulting in a widening disequilibrium between material inflows and outflows; the amount of materials extracted during this period increased 16-fold, whilst the rate of input materials that are (re) cycled almost halved from $43 \%$ to $27 \%$. $^{7}$ After recognizing the unsustainability of this uninhibited utilization of scarce resources, the concept of a circular economy (CE) was established, ${ }^{6}$ dictating that manufactured products and used materials should remain in circulation for as long as possible before being recycled or finally disposed. This restorative or regenerative circular approach to resource utilization creates an opportunity to minimize unnecessary waste output through improved resource efficiencies, offered by long-lasting medical devices that allow for reuse, repair, remanufacturing, or high quality recycling. ${ }^{8}$ This CE approach strives to slow, narrow and close socioeconomic material cycles, ${ }^{9}$ by reducing absolute material flows. $^{3,7,10}$ It is fundamentally different to a traditional linear economy whereby raw materials are collected, transformed into products, used once, and discarded as waste.

Within the hospital, surgery is recognized as a resource-intensive activity that follows principles of the linear economy, disproportionately generating large volumes of healthcare waste. ${ }^{11-13}$ Around one-third of waste generated by the healthcare system is estimated to originate from the operating room (OR),${ }^{14}$ with US ORs producing an estimated 730,500 tons of waste each year. ${ }^{15}$ Of the OR waste produced, up to $90 \%$ is wrongly classified as biohazardous waste, meaning it cannot be repurposed, reduced, or recycled, but has to be treated in a manner which prevents any future health risks. $^{12}$ Misclassification also has cost implications, given that treatment and disposal of biohazardous waste can cost up to 20-times more than non-hazardous waste. ${ }^{12}$ Further, the extensive use and convenience of single-use, disposable medical supplies has contributed substantially the problem of health-sector waste, and more broadly to the problem of scarce resource depletion. ${ }^{12,16}$ As such, tackling the ORs reliance on single-use disposable medical devices and ensuring that resources are used efficiently represents an "area of highest impact for health-care decarbonization" and resource savings. ${ }^{16,17}$
Given that there are a large number of OR procedures applying surgical stapling techniques, procedures using these techniques are of interest for assessing the extent to which resource management efficiencies can be achieved. Although stapling techniques are used across a range of procedures, to the best of our knowledge to date, no publication attempts to assess resource consumption and waste-reduction in the context of surgical stapling.

The primary focus of this analysis is therefore to evaluate the waste prevention potential and extended resource use of multi-use versus single-use powered surgical stapling systems. A CE approach is used to understand whether transitioning from a single-use system (SUS) to a multi-use system (MUS) could facilitate a more efficient use of scarce resources and contribute to healthcare providers' aims of protecting these resources, whilst also reducing total medical waste.

\section{Materials and Methods Overview of Analysis Methodology}

Surgery often involves the separation or removal of tissue, which requires the subsequent approximation of tissue to close the wound. Surgical stapling is one method of closure. This analysis compares two frequently used surgical, laparoscopic stapling systems; Ethicon's SUS: ECHELON FLEX $^{\mathrm{TM}}$, and Medtronic's MUS: Signia ${ }^{\mathrm{TM}}$ Stapling Technology. ${ }^{18}$ Modern surgical stapling systems come in a variety of forms and functions depending on the surgical application. Generally, each stapler features a power handle (including battery) which is held by the surgeon, an adapter which is fixed to the power handle, and attached to the end of the adapter is a disposable cartridge holder which houses the staples. The key steps of the approach taken in this study are summarized in Table 1.

\section{Product Material Analysis}

The first stage of the analysis was the product material analysis. This involved disassembling the SUS and MUS (excluding all product and sales packaging) to their individual raw-material components and calculating the total weight of each component (composed of multiple raw materials). The types of raw materials in each component were then identified by measuring material density as well as through visual inspection. Finally, the total weight of each material was calculated to understand the material composition of each system.

For the SUS, the products PVE35A, VASECR35, ECR45G, PSEE60A, and ECR60W were mechanically 
Table I Study Process Overview

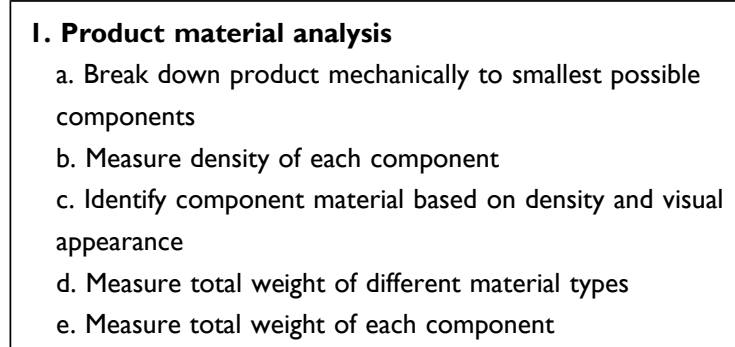

\section{Waste generation}

a. Based on the assumed number of device components used per surgical procedure, calculate the surgical stapling system waste from each procedure

b. Calculate waste prevention by switching from the SUS to MUS

\section{Total material requirement (TMR)}

a. Based on each component's total weight (calculated in Product material analysis step), calculate the TMR of each component

b. Calculate total TMR of the SUS and MUS

c. Calculate total TMR for different surgical procedures

d. Calculate resource saving by switching from the SUS to MUS

\section{Sensitivity analyses}

a. Utilize alternative calculation assumptions and inputs to assess the level of confidence associated with results and understand how responsive the model is to alternative assumptions

b. Understand how many times the multi-use components of the MUS must be used to facilitate a reduction in total waste generated and TMR when switching from a SUS to a MUS

Abbreviations: kg, kilogram; MUS, multi-use system; SUS, single-use system; TMR, total material requirement.

deconstructed and assessed. No component of the SUS is reusable. A PSEE45A power adapter and handle was not mechanically deconstructed and assessed given that the product length of the PSEE45A is identical to the PSEE60A. For the MUS, the reusable product components SIGPHANDLE, SIGADAPTSTND, SIGRIG, SIGSBCHGR, and the singleuse components SIGPSHELL, EGIA30XXX, EGIA45XXX, and EGIA60XXX were analyzed. Product components ending XXX indicate that different cartridge holder options are available to the surgeon when operating on different tissue thicknesses, but the core component (and therefore the component's mass) is unchanged. The surgical stapling systems included in this analysis and their corresponding components and component product codes are summarized in Table 2.

\section{Waste Generation}

Based on the results of the product material analysis, the second stage of the study was to understand how much waste would be generated when SUSs or MUSs are used in clinical practice. The power handle and adapter of the SUS can
Table 2 Surgical Stapling System Components

\begin{tabular}{|c|c|c|}
\hline $\begin{array}{l}\text { Surgical } \\
\text { Stapling System } \\
\text { (Manufacturer) }\end{array}$ & $\begin{array}{l}\text { Component } \\
\text { Product Code }\end{array}$ & System Component \\
\hline $\begin{array}{l}\text { SUS: ECHELON } \\
\text { FLEX }^{\mathrm{TM}} \text { (Ethicon) }\end{array}$ & $\begin{array}{l}\text { PVE35A } \\
\text { PSEE60A } \\
\text { VASECR35 } \\
\text { ECR45G } \\
\text { ECR60W }\end{array}$ & $\begin{array}{l}35 \mathrm{~mm} \text { power handle and } \\
\text { adapter } \\
60 \mathrm{~mm} \text { power handle and } \\
\text { adapter } \\
35 \mathrm{~mm} \text { cartridge holder } \\
45 \mathrm{~mm} \text { cartridge holder } \\
60 \mathrm{~mm} \text { cartridge holder }\end{array}$ \\
\hline $\begin{array}{l}\text { MUS: Signia }{ }^{\mathrm{TM}} \\
\text { Stapling } \\
\text { Technology } \\
\text { (Medtronic) }\end{array}$ & $\begin{array}{l}\text { SIGPSHELL } \\
\text { SIGPHANDLE } \\
\text { SIGADAPTSTND } \\
\text { SIGRIG } \\
\text { SIGSBCHGR } \\
\text { EGIA30XXX } \\
\text { EGIA45XXX } \\
\text { EGIA60XXX }\end{array}$ & $\begin{array}{l}\text { Power shell to cover } \\
\text { power handle } \\
\text { Power handle } \\
\text { Adapter } \\
\text { Insertion guide } \\
\text { Charging station } \\
30 \mathrm{~mm} \text { cartridge holder } \\
45 \mathrm{~mm} \text { cartridge holder } \\
60 \mathrm{~mm} \text { cartridge holder }\end{array}$ \\
\hline
\end{tabular}

Abbreviations: mm, millimeter; MUS, multi-use system; SUS, single-use system.

be used multiple times per procedure but must be disposed of after each surgery, and the SUS cartridge holders must be disposed of after each firing. For the MUS, the power shell is disposed of after each surgery and the cartridges are disposed of after each firing. However, the device handle, adapter, insertion guide, and charging station are reusable and should only be replaced after a pre-defined number of uses. These device component replacement frequencies, presented as circulation ratios, are shown in Table 3. To estimate the share of waste related to one use circle, the total waste generated was divided by the number of uses possible (the circulation ratio).

Three surgical procedures requiring stapling techniques were selected for this comparative analysis. These procedures are laparoscopic sleeve gastrectomy, laparoscopic gastric bypass, and video-assisted thoracoscopic (VATS) lobectomy. For each of these procedures, the functional unit is defined by the product parts required to perform each procedure. Although cartridge use is likely to vary across surgical practice, clinical expert opinion was sought to estimate the expected number and type of stapling cartridges needed for each surgery of interest. The number and length of cartridges required per procedure differs. These estimates are presented in Table 4.

With these component-specific circulation ratios, as well as an estimate of the average number and length of cartridges required during each surgical procedure, system waste accumulated per procedure was calculated. 
Table 3 Surgical Stapling System Component Specifications

\begin{tabular}{|c|c|c|c|}
\hline Surgical Stapling System (Manufacturer) & System Component (Product Code) & Unit & Circulation Ratio \\
\hline SUS: ECHELON FLEX ${ }^{\mathrm{TM}}$ (Ethicon) & $\begin{array}{l}35 \mathrm{~mm} \text { power handle and adapter (PVE35A) } \\
60 \mathrm{~mm} \text { power handle and adapter (PSEE60A) } \\
35 \mathrm{~mm} \text { cartridge holder (VASECR35) } \\
45 \mathrm{~mm} \text { cartridge holder (ECR45G) } \\
60 \mathrm{~mm} \text { cartridge holder (ECR60W) }\end{array}$ & $\begin{array}{l}\text { Surgery } \\
\text { Surgery } \\
\text { Firing } \\
\text { Firing } \\
\text { Firing }\end{array}$ & $\begin{array}{l}1 \\
1 \\
1 \\
1 \\
1\end{array}$ \\
\hline MUS: Signia ${ }^{\mathrm{TM}}$ Stapling Technology (Medtronic) & $\begin{array}{l}\text { Power shell to cover power handle (SIGPSHELL) } \\
\text { Power handle (SIGPHANDLE) } \\
\text { Adapter (SIGADAPTSTND) } \\
\text { Insertion guide (SIGRIG) } \\
\text { Charging station (SIGSBCHGR) } \\
30 \mathrm{~mm} \text { cartridge holder (EGIA30XXX) } \\
45 \mathrm{~mm} \text { cartridge holder (EGIA45XXX) } \\
60 \mathrm{~mm} \text { cartridge holder (EGIA60XXX) }\end{array}$ & $\begin{array}{l}\text { Surgery } \\
\text { Surgery } \\
\text { Surgery } \\
\text { Surgery } \\
\text { Surgery } \\
\text { Firing } \\
\text { Firing } \\
\text { Firing }\end{array}$ & $\begin{array}{l}1 \\
300 \\
50 \\
300 \\
5000 \\
1 \\
1 \\
1\end{array}$ \\
\hline
\end{tabular}

Notes: Circulation ratios indicate how often a device component can be reused and are based on the possible maximum number of uses - for example, SIGPHANDLE has a circulation ratio of 300 meaning that each power handle (SIGPHANDLE) can be reused up to 300 times before needing to be replaced. MUS component circulation ratios are based on useful life estimates. ${ }^{28}$ The MUS display screen includes status indicators for the power handle (SIGPHANDLE) and adapter (SIGADAPTSTND) to ensure that these instruments cannot be used more than their maximum number of possible uses. ${ }^{29}$

Abbreviations: mm, millimeter; MUS, multi-use system; SUS, single-use system.

Table 4 Average Cartridge Use per Procedure

\begin{tabular}{|l|l|l|l|}
\hline Surgery Grouping & Surgery Type & Cartridge Type & Expected Number of Cartridges Used \\
\hline Bariatric & Laparoscopic sleeve gastrectomy & $60 \mathrm{~mm}$ & 5 \\
& Laparoscopic gastric bypass & $30 \mathrm{~mm}$ & 1 \\
& & $45 \mathrm{~mm}$ & 2 \\
& & $60 \mathrm{~mm}$ & 2 \\
\hline Thoracic & VATS lobectomy & $30 \mathrm{~mm}$ & 2 \\
& & $45 \mathrm{~mm}$ & 1 \\
& & $60 \mathrm{~mm}$ & 4 \\
\hline
\end{tabular}

Notes: The average number of cartridges used presented here does not reflect any guidelines and are based on personal communication with two practicing surgeons as detailed in acknowledgements. It is understood that surgical practice differs from place to place, surgeon to surgeon, and patient to patient. For surgeries which require multiple cartridge lengths, with the SUS it will be assumed that the $45 \mathrm{~mm}$ cartridge can be used with the 60 mm power handle and adapter but cannot be used with the $35 \mathrm{~mm}$ power handle and adapter. As such, it is assumed that two SUS power handles and adapters are required by the surgeon for each of these procedures. Separate devices are not required when using the MUS to accommodate the different cartridge length requirements.

Abbreviations: $\mathrm{mm}$, millimeter; VATS, video-assisted thoracoscopic.

Additionally, the waste prevention potential of switching from a SUS to MUS was calculated by comparing the total waste generated per device for each surgical procedure.

\section{TMR}

The third stage of the study was to compute the total material requirement (TMR) associated with each component and system. TMR, based on the concept of material input per service, is a metric which reflects all abiotic and biotic material as well as the moved soil needed to manufacture a product or a service. The use of air and water in the production process is not taken into consideration in this metric. ${ }^{19,20}$ For the calculation, the material composition of a product is analyzed. The masses of all used elements are multiplied with specific TMR- coefficients that reflect the primary material use. Therefore, TMR expresses the cumulative mass of primary materials which are extracted for the analyzed product and can be summarized as an indicator for the material intensity of the product. ${ }^{21}$ In the context of this analysis, calculating the TMR of each system provides an estimate of the natural resource burden linked to each system. This approach differs to a lifecycle assessment (LCA) given that the TMR considers a narrower range of ecological impacts and does not account for end-of-life scenarios.

Based on the material composition and weight of each system, a TMR was calculated for each component (excluding product and sales packaging). The TMR of each system component was then extrapolated to calculate the upstream 
Table 5 Surgical Stapling System Material Composition

\begin{tabular}{|l|l|l|}
\hline Surgical Stapling System (Manufacturer) & System Component (Product Code) & Component Weight (g) \\
\hline SUS: ECHELON FLEX ${ }^{T M}$ (Ethicon) & $35 \mathrm{~mm}$ power handle and adapter (PVE35A) & $661.16 \mathrm{~g}$ \\
& $60 \mathrm{~mm}$ power handle and adapter (PSEE60A) & $688.53 \mathrm{~g}$ \\
& $35 \mathrm{~mm}$ cartridge holder (VASECR35) & $5.67 \mathrm{~g}$ \\
& $45 \mathrm{~mm}$ cartridge holder (ECR45G) & $6.47 \mathrm{~g}$ \\
\hline MUS: Signia ${ }^{\text {TM }}$ Stapling Technology (Medtronic) & $60 \mathrm{~mm}$ cartridge holder (ECR60W) & $125.40 \mathrm{~g}$ \\
& Power shell to cover power handle (SIGPSHELL) & $456.03 \mathrm{~g}$ \\
& Power handle (SIGPHANDLE) & $184.27 \mathrm{~g}$ \\
& Adapter (SIGADAPTSTND) & $79.3 \mathrm{~g}$ \\
& Insertion guide (SIGRIG) & $708.93 \mathrm{~g}$ \\
& Charging station (SIGSBCHGR) & $53.33 \mathrm{~g}$ \\
& $30 \mathrm{~mm}$ cartridge holder (EGIA30XXX) & $55.20 \mathrm{~g}$ \\
& $45 \mathrm{~mm}$ cartridge holder (EGIA45XXX) & $59.80 \mathrm{~g}$ \\
\hline
\end{tabular}

Abbreviations: g, gram; mm, millimeter; MUS, multi-use system; SUS, single-use system.

resource use associated with each surgery (laparoscopic sleeve gastrectomy, laparoscopic gastric bypass, and VATS lobectomy).

\section{Sensitivity Analysis}

Finally, sensitivity analyses were conducted to understand how results of this study would be impacted under different input assumptions, to identify dependencies and strengthen conclusions. $^{22}$ Specifically, varying the level of usage associated with each multi-use component (circulation ratios) was explored to identify the impact this would have on waste prevention potential and extended resource use (TMR) results.

\section{Results}

\section{Product Material Analysis}

Following mechanical deconstruction, the total weight of each system component was calculated. These results are summarized in Table 5. The material composition of each stapling system (grouped as either circuit boards, motor, glass, metals, plastics, or other) was also calculated. This was calculated for appropriate combinations of cartridge holders (for example, the SUS's $35 \mathrm{~mm}$ cartridge holder [VASSECR35] cannot be used with the $60 \mathrm{~mm}$ power handle and adapter [PSEE60A]). The total weight of each surgical stapling system is presented in Table 6 .

Table 6 Surgical Stapling System Combined Component Material Analysis Results

\begin{tabular}{|c|c|c|c|c|c|c|}
\hline \multirow[t]{3}{*}{ Material } & \multicolumn{6}{|c|}{ Single Surgical Stapling System Material Weights with Appropriate Reloads (g) } \\
\hline & \multicolumn{3}{|l|}{ SUS } & \multicolumn{3}{|l|}{ MUS } \\
\hline & $\begin{array}{l}\text { VASECR35 } \\
\text { (PVE35A, } \\
\text { VASECR35) }\end{array}$ & $\begin{array}{l}\text { ECR45 } \\
\text { (PSEE60A, } \\
\text { ECR45G) }\end{array}$ & $\begin{array}{l}\text { ECR60 } \\
\text { (PSEE60A, } \\
\text { ECR60G) }\end{array}$ & $\begin{array}{l}\text { EGIA30XXX } \\
\text { (SIGPSHELL, } \\
\text { SIGPHANDLE, } \\
\text { SIGADAPTSTND, } \\
\text { SIGRIG, } \\
\text { SIGSBCHGR, } \\
\text { EGIA30XXX) }\end{array}$ & $\begin{array}{l}\text { EGIA45XXX } \\
\text { (SIGPSHELL, } \\
\text { SIGPHANDLE, } \\
\text { SIGADAPTSTND, } \\
\text { SIGRIG, } \\
\text { SIGSBCHGR, } \\
\text { EGIA45XXX) }\end{array}$ & $\begin{array}{l}\text { EGIA60XXX } \\
\text { (SIGPSHELL, } \\
\text { SIGPHANDLE, } \\
\text { SIGADAPTSTND, } \\
\text { SIGRIG, } \\
\text { SIGSBCHGR, } \\
\text { EGIA60XXX) }\end{array}$ \\
\hline Circuit board & $22.67 \mathrm{~g}$ & $22.90 \mathrm{~g}$ & $22.90 \mathrm{~g}$ & $120.16 \mathrm{~g}$ & $120.16 \mathrm{~g}$ & $120.16 \mathrm{~g}$ \\
\hline Motor & $44.79 \mathrm{~g}$ & $47.20 \mathrm{~g}$ & $47.20 \mathrm{~g}$ & $73.13 \mathrm{~g}$ & $73.13 \mathrm{~g}$ & $73.13 \mathrm{~g}$ \\
\hline Glass & $0.00 \mathrm{~g}$ & $0.00 \mathrm{~g}$ & $0.00 \mathrm{~g}$ & $1.08 \mathrm{~g}$ & $1.12 \mathrm{~g}$ & $1.21 \mathrm{~g}$ \\
\hline Metal & $263.76 \mathrm{~g}$ & $288.22 \mathrm{~g}$ & $288.43 \mathrm{~g}$ & $259.71 \mathrm{~g}$ & $260.99 \mathrm{~g}$ & $264.13 \mathrm{~g}$ \\
\hline Plastics & $242.29 \mathrm{~g}$ & $244.50 \mathrm{~g}$ & $245.15 \mathrm{~g}$ & $786.64 \mathrm{~g}$ & $787.10 \mathrm{~g}$ & $788.22 \mathrm{~g}$ \\
\hline Other & $91.32 \mathrm{~g}$ & $91.32 \mathrm{~g}$ & $91.32 \mathrm{~g}$ & $366.55 \mathrm{~g}$ & $366.64 \mathrm{~g}$ & $366.88 \mathrm{~g}$ \\
\hline Total & $664.83 \mathrm{~g}$ & $694.14 \mathrm{~g}$ & $695.00 \mathrm{~g}$ & $1607.27 \mathrm{~g}$ & $1609.14 \mathrm{~g}$ & $1613.74 \mathrm{~g}$ \\
\hline
\end{tabular}

Notes: Switching adapter, secondary battery, and carbon components are categorized as "Other". The system total presented in the table above accounts for all system components required for administering a single staple. That is, multiple cartridge reloads, or multiple cartridge sizes are not accounted for in these totals.

Abbreviations: g, gram; MUS, multi-use system; SUS, single-use system. 
Mechanically deconstructing and analyzing the make-up of each system (Table 6) revealed that the SUS and MUS are manufactured from a variety of different materials, with the composition of the MUS requiring more materials than the SUS. As shown in Table 6, there is no glass in the SUS, and it is manufactured from fewer thermoplastics than the MUS. The SUS, with either the VASECR35, ECR45, or ECR60 cartridge holders attached, had a total mass of $664.83 \mathrm{~g}, 694.14 \mathrm{~g}$, and $695.00 \mathrm{~g}$, respectively, with the greatest share of mass attributed to metals ( $40 \%, 42 \%$, and $42 \%$ of total mass). By comparison, the MUS, with either the EGIA30XXX, EGIA45XXX, or EGIA60XXX cartridge holders attached, had a total mass of $1607.27 \mathrm{~g}, 1609.14$, and $1613.74 \mathrm{~g}$, respectively, with plastics constituting the greatest share of total mass ( $49 \%$ for each surgical procedure considered).

\section{Waste Generation}

Based on the device component weights determined by the material composition analysis (Table 5) and the expected circulation ratio of each component per procedure (Table 4), total waste for each system was determined.
Total waste accumulated using the SUS versus MUS for different surgical procedures is presented in Table 7 and reveals that compared to the SUS, use of the MUS leads to a reduction in the total amount of system waste accumulated per surgical procedure. For each surgery considered, switching from the SUS to the MUS results in a reduction in the amount of accumulated waste by $-0.29 \mathrm{~kg},-0.96 \mathrm{~kg}$, and $-0.86 \mathrm{~kg}$ for sleeve gastrectomy, gastric bypass, and VATS lobectomy, respectively. This reduction in system waste translates to a waste prevention potential of $40 \%$ for laparoscopic sleeve gastrectomy, $70 \%$ for laparoscopic gastric bypass, and $62 \%$ for VATS lobectomy procedures.

\section{TMR}

Using total component weights and the material type (TMRfactors) identified following mechanical deconstruction of each system, TMR was calculated for each component use to evaluate its extended resource use. TMR results are presented in Table 8 for each system component. These results show that the TMR of the SUS $60 \mathrm{~mm}$ power handle and adapter (PSEE60A) is the most resource-intensive

Table 7 Total Waste Generated per Surgery

\begin{tabular}{|l|l|l|l|l|}
\hline \multirow{2}{*}{$\begin{array}{l}\text { Surgery } \\
\text { Grouping }\end{array}$} & Surgery Type & \multicolumn{2}{|l|}{$\begin{array}{l}\text { Total Weight of Accumulated } \\
\text { Waste per Surgery (kg) }\end{array}$} & $\begin{array}{l}\text { Change in Total Accumulated Waste } \\
\text { Switching from SUS to MUS (kg) }\end{array}$ \\
\cline { 3 - 4 } & & SUS & MUS & \\
\hline Bariatric & Laparoscopic sleeve gastrectomy & $0.72 \mathrm{~kg}$ & $0.43 \mathrm{~kg}$ & $-0.29 \mathrm{~kg}$ \\
& Laparoscopic gastric bypass & $1.38 \mathrm{~kg}$ & $0.41 \mathrm{~kg}$ & $-0.96 \mathrm{~kg}$ \\
\hline Thoracic & VATS lobectomy & $1.39 \mathrm{~kg}$ & $0.53 \mathrm{~kg}$ & $-0.86 \mathrm{~kg}$ \\
\hline
\end{tabular}

Abbreviations: kg, kilogram; MUS, multi-use system; SUS, single-use system; VATS, video-assisted thoracoscopic.

Table 8 Surgical Stapling System TMR

\begin{tabular}{|c|c|c|}
\hline Surgical Stapling System (Manufacturer) & System Component (Product Code) & TMR of Component (g) \\
\hline SUS: ECHELON FLEX ${ }^{\mathrm{TM}}$ (Ethicon) & $\begin{array}{l}35 \mathrm{~mm} \text { power handle and adapter (PVE35A) } \\
60 \mathrm{~mm} \text { power handle and adapter (PSEE60A) } \\
35 \mathrm{~mm} \text { cartridge holder (VASECR35) } \\
45 \mathrm{~mm} \text { cartridge holder (ECR45G) } \\
60 \mathrm{~mm} \text { cartridge holder (ECR60W) }\end{array}$ & $\begin{array}{l}303,936 \mathrm{~g}(304 \mathrm{~kg}) \\
328,366 \mathrm{~g}(328 \mathrm{~kg}) \\
95 \mathrm{~g} \\
144 \mathrm{~g} \\
169 \mathrm{~g}\end{array}$ \\
\hline MUS: Signia ${ }^{\text {TM }}$ Stapling Technology (Medtronic) & $\begin{array}{l}\text { Power shell to cover power handle (SIGPSHELL) } \\
\text { Power handle (SIGPHANDLE) } \\
\text { Adapter (SIGADAPTSTND) } \\
\text { Insertion guide (SIGRIG) } \\
\text { Charging station (SIGSBCHGR) } \\
30 \mathrm{~mm} \text { cartridge holder (EGIA30XXX) } \\
45 \mathrm{~mm} \text { cartridge holder (EGIA45XXX) } \\
60 \mathrm{~mm} \text { cartridge holder (EGIA60XXX) }\end{array}$ & $\begin{array}{l}820 \mathrm{~g} \\
559,960 \mathrm{~g}(560 \mathrm{~kg}) \\
88,670 \mathrm{~g}(89 \mathrm{~kg}) \\
200 \mathrm{~g} \\
231,080 \mathrm{~g}(231 \mathrm{~kg}) \\
3940 \mathrm{~g} \\
4078 \mathrm{~g} \\
4418 \mathrm{~g}\end{array}$ \\
\hline
\end{tabular}

Abbreviations: g, gram; kg, kilogram; MUS, multi-use system; SUS, single-use system; TMR, total material requirement. 
Table 9 TMR per Surgery Type

\begin{tabular}{|l|l|l|l|l|}
\hline \multirow{2}{*}{$\begin{array}{l}\text { Surgery } \\
\text { Grouping }\end{array}$} & Surgery Type & \multicolumn{2}{l|}{ TMR per Surgery Type (kg) } & \multirow{2}{*}{$\begin{array}{l}\text { Change in TMR Switching From } \\
\text { SUS to MUS (kg) }\end{array}$} \\
\cline { 3 - 4 } & & SUS & MUS & \\
\hline Bariatric & Laparoscopic sleeve gastrectomy & $329 \mathrm{~kg}$ & $27 \mathrm{~kg}$ & $-303 \mathrm{~kg}$ \\
& Laparoscopic gastric bypass & $633 \mathrm{~kg}$ & $25 \mathrm{~kg}$ & $-608 \mathrm{~kg}$ \\
Thoracic & VATS lobectomy & $633 \mathrm{~kg}$ & $34 \mathrm{~kg}$ & $-599 \mathrm{~kg}$ \\
\hline
\end{tabular}

Abbreviations: kg, kilogram; MUS, multi-use system; SUS, single-use system; TMR, total material requirement; VATS, video-assisted thoracoscopic.

component of the SUS, requiring $328 \mathrm{~kg}$ of resources for its production. The most resource-intensive component of the MUS was the handle (SIGPHANDLE), requiring $560 \mathrm{~kg}$ of resources. The TMR of all cartridge holders (EGIA30XXX, EGIA45XXX, and EGIA60XXX) required for the MUS were substantially greater than the TMR for cartridge holders required for the SUS.

After factoring in component reuse during surgery, the TMRs associated with each product component were calculated and the results are presented in Table 9. Table 9 shows that the reduction in TMR for surgical procedures when switching from a SUS to a MUS is substantial. The TMR drops from $329 \mathrm{~kg}$ to $27 \mathrm{~kg}$ for laparoscopic sleeve gastrectomy, $633 \mathrm{~kg}$ to $25 \mathrm{~kg}$ for laparoscopic gastric bypass, and $633 \mathrm{~kg}$ to $34 \mathrm{~kg}$ for VATS lobectomy. In all three procedures, the per-procedure TMR is reduced by over $90 \%$, suggesting that over $90 \%$ of total raw material inputs utilized in the production of the SUS can be saved by switching to use of the MUS.

\section{Sensitivity Analysis}

To examine the importance of reusing product components where possible, a sensitivity analysis was conducted calculating total waste generated and TMR for each surgical procedure where MUS components were used suboptimally before being disposed of. The results of these sensitivity analyses are presented in Table 10 .

These results show that if the MUS were disposed of after a single use for these surgeries, waste generation and resource use of the MUS would exceed that of the SUS. In the single-use MUS scenario, waste generation increases by $1.13 \mathrm{~kg}$ for laparoscopic sleeve gastrectomy, $0.46 \mathrm{~kg}$ for laparoscopic gastric bypass, and $0.57 \mathrm{~kg}$ for VATS lobectomy when compared to SUS. TMR rises by $574 \mathrm{~kg}, 269 \mathrm{~kg}$, and $277 \mathrm{~kg}$ across these respective surgical procedures. If each MUS multi-use component were utilized half of the number of times that they should maximally be used for, total waste accumulated and
TMR per surgery for MUSs would still be lower than with the SUS.

Figure 1 presents sensitivity results where total waste and TMR are calculated for each surgery type considered whilst varying the number of times that each multi-use component is reused between one and ten. For laparoscopic sleeve gastrectomy, multi-use components must be reused at least five times for the total waste generated during the procedure with the MUS to be lower than with the SUS. Figure 1 also shows that to achieve a lower TMR with the MUS than the SUS, the multi-use MUS components must be used at least three times. The required number of reuses for other surgery types are also shown in Figure 1. These results highlight the importance of reusing MUS components where possible and indicate that results are highly (or even totally) independent to lower circulation rates.

\section{Discussion}

By implementing CE principles in the OR through switching to MUSs as opposed to SUS, this analysis suggests that total volumes of operating room waste accumulated during different procedures can be reduced substantially. Little published evidence exists which evaluates high volume products, such as single-use surgical stapling devices. With this study we fill an important evidence gap and thus support hospital decision makers in transitioning from a linear to a $\mathrm{CE}$ resource consumption model.

Based on the results of this analysis, in clinical practice the potential to reduce operating room waste by applying CE principles is considerable. For example, UK NHS Reference Costs 2018-2019 report that 2130 sleeve gastrectomy for obesity procedures (FF12Z) were undertaken across all NHS trusts and NHS foundation trusts. ${ }^{23}$ If all these procedures were performed by surgeons using SUSs, the total waste generated and TMR for these procedures would amount to $1535 \mathrm{~kg}$ and $701,219 \mathrm{~kg}$, respectively. However, if a multi-use system were instead used, the total accumulated waste and TMR these sleeve gastrectomy for 
Table 10 Sensitivity Analysis Results

\begin{tabular}{|c|c|c|c|c|c|}
\hline $\begin{array}{l}\text { Surgery } \\
\text { Grouping }\end{array}$ & Surgery Type & Result Metric & sus & MUS & $\begin{array}{l}\text { Change Due to } \\
\text { Switching } \\
\text { From SUS to } \\
\text { MUS (kg) }\end{array}$ \\
\hline \multicolumn{6}{|c|}{ All device components disposed after I unit } \\
\hline \multirow[t]{4}{*}{ Bariatric } & \multirow{2}{*}{$\begin{array}{l}\text { Laparoscopic sleeve } \\
\text { gastrectomy }\end{array}$} & Total weight $(\mathrm{kg})$ & $0.72 \mathrm{~kg}$ & $1.85 \mathrm{~kg}$ & $+1.13 \mathrm{~kg}$ \\
\hline & & TMR (kg) & $329 \mathrm{~kg}$ & $903 \mathrm{~kg}$ & $+574 \mathrm{~kg}$ \\
\hline & \multirow{2}{*}{$\begin{array}{l}\text { Laparoscopic gastric } \\
\text { bypass }\end{array}$} & Total weight $(\mathrm{kg})$ & $1.38 \mathrm{~kg}$ & $1.84 \mathrm{~kg}$ & $+0.46 \mathrm{~kg}$ \\
\hline & & TMR (kg) & $633 \mathrm{~kg}$ & $902 \mathrm{~kg}$ & $+269 \mathrm{~kg}$ \\
\hline \multirow[t]{2}{*}{ Thoracic } & \multirow[t]{2}{*}{ VATS lobectomy } & Total weight $(\mathrm{kg})$ & $1.39 \mathrm{~kg}$ & $1.96 \mathrm{~kg}$ & $+0.57 \mathrm{~kg}$ \\
\hline & & TMR (kg) & $633 \mathrm{~kg}$ & $910 \mathrm{~kg}$ & $+277 \mathrm{~kg}$ \\
\hline \multicolumn{6}{|c|}{ All multi-use device components used $50 \%$ optimally } \\
\hline \multirow[t]{4}{*}{ Bariatric } & \multirow{2}{*}{$\begin{array}{l}\text { Laparoscopic sleeve } \\
\text { gastrectomy }\end{array}$} & Total weight (kg) & $0.72 \mathrm{~kg}$ & $0.44 \mathrm{~kg}$ & $-0.29 \mathrm{~kg}$ \\
\hline & & TMR (kg) & $329 \mathrm{~kg}$ & $30 \mathrm{~kg}$ & $-299 \mathrm{~kg}$ \\
\hline & \multirow{2}{*}{$\begin{array}{l}\text { Laparoscopic gastric } \\
\text { bypass }\end{array}$} & Total weight $(\mathrm{kg})$ & $1.38 \mathrm{~kg}$ & $0.42 \mathrm{~kg}$ & $-0.96 \mathrm{~kg}$ \\
\hline & & TMR (kg) & $633 \mathrm{~kg}$ & $29 \mathrm{~kg}$ & $-604 \mathrm{~kg}$ \\
\hline \multirow[t]{2}{*}{ Thoracic } & \multirow[t]{2}{*}{ VATS lobectomy } & Total weight $(\mathrm{kg})$ & $1.39 \mathrm{~kg}$ & $0.54 \mathrm{~kg}$ & $-0.85 \mathrm{~kg}$ \\
\hline & & TMR (kg) & $633 \mathrm{~kg}$ & $38 \mathrm{~kg}$ & $-595 \mathrm{~kg}$ \\
\hline
\end{tabular}

Notes: Calculation of TMR per procedure based on component replacement frequency, average cartridge use, and calculated TMRs.

Abbreviations: kg, kilogram; MUS, multi-use system; SUS, single-use system; TMR, total material requirement; VATS, video-assisted thoracoscopic.

obesity procedures would have amounted to $916 \mathrm{~kg}$ and $56,649 \mathrm{~kg}$, respectively. Switching from a SUS to MUS for these procedures therefore equates to a $620 \mathrm{~kg}(40 \%)$ reduction in total waste accumulated, and a $644,571 \mathrm{~kg}$ (92\%) reduction in TMR. Given that the NHS have also pledged to reduce reliance on disposable plastics, with a short-term aim to reduce clinical single-use plastics by $10 \%$, evaluating the typical use of single-use systems in clinical practice presents an opportunity to realize this target. $^{24}$

In terms of costs, a Royal College of Nursing report found that the median cost per ton of infectious (yellow-bagged) waste was $£ 475$, amounting to $£ 0.48$ per $\mathrm{kg}^{25}$ Applied to the NHS example of sleeve gastrectomy (for obesity procedures), the cost of disposing of the waste produced by SUSs (1535 kg) would equate to $£ 729$, versus $£ 435$ for the cost of disposing of waste produced by MUSs $(916 \mathrm{~kg})$. This simplified calculation reveals a cost saving of $£ 294$ for these procedures, suggesting that the environmental benefits of CE may also yield monetary benefits. After signing up to the NHS Plastics Reduction Pledge in 2019/20, the Yorkshire Ambulance Service NHS
Trust recorded a four-ton reduction in total annual waste which led to a $£ 12,000$ saving in packaging, delivery, and disposal costs, ${ }^{24}$ confirming that $\mathrm{CE}$ principles can lead to economic benefits.

Although the results of this analysis are promising, this study contains limitations. Firstly, this analysis only considers one brand of SUS and one brand of MUS, but it is unlikely that in clinical practice these are the only stapling devices used by hospitals. The material composition of alternative SUSs or MUSs used in clinical practice may also differ to that of the devices analyzed here, and this may lead to different results and conclusions. For example, only the "standard" shaft length SUS staplers were considered in this analysis. The "compact" and "long" models were not analyzed, but if they were used in lieu of the "standard" SUS for some procedures, then results would be expected to differ slightly given that the overall material composition of these devices differs. As such, the results presented in this analysis should only be considered within the context of this study, and further analyses should be conducted at the hospital level for alternative devices of interest. 


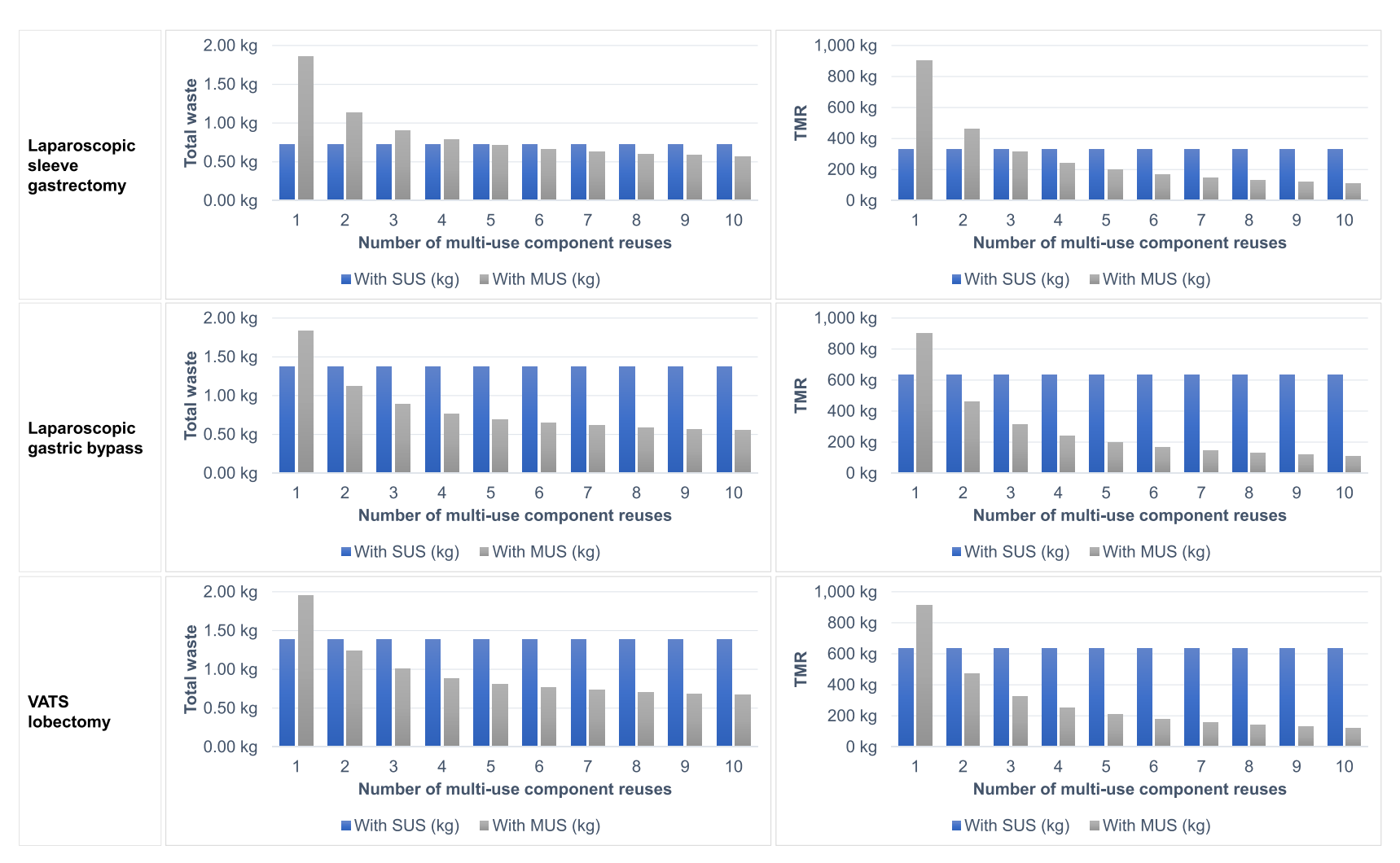

Figure I Sensitivity analysis: Total waste and TMR subject to the number of multi-use component reuses for the three selected surgical procedures. Abbreviations: kg, kilogram; MUS, multi-use system; SUS, single-use system; TMR, total material requirement; VATS, video-assisted thoracoscopic.

An additional study limitation is that system costs were excluded from this analysis. Within the recent past, both the widespread adoption of single-use, low-cost technologies, which allowed manufacturers of complex medical devices to manufacturer devices using low-cost plastics, and the rapid uptake of minimally invasive surgical techniques, have led to an influx of complex, high-frequency use medical devices (such as surgical stapling devices) in the market. ${ }^{6}$ Paired with highly limited hospital budgets, these low-cost technologies have helped to keep the per device hospital spend on some medical devices low, arguably at the expense of the environment. Moving forward, cost will remain a key driver of decisions at the hospital payer level, and the expected higher upfront purchase cost of MUSs, as well as other reusable medical technologies, may hinder uptake. It is therefore important that more detailed analyses, exploring the cost implications of reusable stapling device uptake at the hospital level, are conducted, to fully understand the budgetary implications of doing so.

Additionally, tackling the notion that single-use disposable technologies are safer than reusable technologies is a challenge which must be overcome to implement lasting change. Patient safety should always remain the priority for providers and device users, and the approach taken in this research assumes that the SUS and MUS are comparable devices in terms of safety profiles. However, it is known that the introduction of single-use medical devices has contributed to a reduction in infection rates, and so using devices which are "single-use" appear to provide device users and purchasers with a safety net by ensuring device sterility. ${ }^{6}$ The US Food and Drug Administration indicated that single-use devices are classified as nonsterile only when the packaging is removed. ${ }^{26}$ This has contributed to the perceived risk to patient health associated with use of reusable devices. The additional steps which would be required to be implemented to ensure the proper use of multi-use devices at the hospital level may be reinforcing a reluctance to deviate from the use of single-use devices. Additional research into appropriate protocols, and the feasibility of implementing these measures, to mitigate this risk of infection, for example for device collection, sterilization decontamination, and storage of items for reuse, needs to be explored. In the context of surgical stapling, the MUS device assessed includes disposable parts, like the power shell to cover 
the power handle, to potentially overcome some of these concerns around contamination.

Finally, analysis of the ecological impacts caused by the production, usage, and disposal of single- versus multi-use devices, in the form of a LCA, was not the within the scope of this analysis. For example, product and sales packaging were excluded from this waste prevention assessment. Furthermore, Leiden and colleagues note that the sterilization process is essential for ensuring low infection rates, and the process itself has a notable environmental impact. ${ }^{27}$ However, this was also excluded from this analysis. Analyzing the complete product life cycle of each stapling system in clinical practice would therefore be essential to fully understand the relevant processes in the product life cycle as well as the ecological impact of both systems.

\section{Conclusion}

We present evidence which supports the switch from a linear to CE approach to waste prevention and resource consumption within the OR. We examined how replacing a SUS with a MUS can lead to a reduction in the total amount of waste accumulated as well as extended resource use (TMR) for laparoscopic sleeve gastrectomy, laparoscopic gastric bypass, and VATS lobectomy procedures. We showed that if the multi-use components of the MUS are used more than once, the reduction in waste and TMR associated with a switch from SUSs to MUSs is maintained for a range of reuses.

\section{Acknowledgments}

The authors would like to acknowledge Wuppertal Institut für Klima, Umwelt, Energie $\mathrm{GmbH}$ for conducting the product material analysis and calculating the TMR of each product component.

The authors would also like to acknowledge Dr Sanjay Purkayastha (St Mary's Hospital) and Dr Tom Routledge (Guy's and St Thomas' Hospitals/King's College School of Medicine) who both provided clinical insight into average cartridge use per procedure.

The authors would additionally like to acknowledge Dr Jasmine Winter Beatty (Imperial College London) who provided insight into the clinical and waste aspects of this study.

\section{Funding}

This study was supported by funding from Medtronic. pulswerk GmbH and Coreva Scientific GmbH \& Co KG received consultancy fees from Medtronic for work related to this manuscript.

\section{Disclosure}

Dr Rhodri Saunders is the founding director and owner of Coreva Scientific. The authors report no other conflicts of interest in this work.

\section{References}

1. Gan CCR, Banwell N, Pascual RS, Chu C, Wang YW. Hospital climate actions and assessment tools: a scoping review protocol. BMJ Open. 2019;9(12):e032561. doi:10.1136/bmjopen-2019-032561

2. Watts N, Amann M, Arnell N, et al. The 2019 report of the lancet countdown on health and climate change: ensuring that the health of a child born today is not defined by a changing climate. Lancet. 2019;394(10211):1836-1878. doi:10.1016/S0140-6736(19)32596-6

3. Krausmann F, Lauk C, Haas W, Wiedenhofer D. From resource extraction to outflows of wastes and emissions: the socioeconomic metabolism of the global economy, 1900-2015. Global Environ Change. 2018;52:131-140. doi:10.1016/j.gloenvcha.2018.07.003

4. Minoglou M, Gerassimidou S, Komilis D. Healthcare waste generation worldwide and its dependence on socio-economic and environmental factors. Sustainability. 2017;9(2):220. doi:10.3390/su9020220

5. Rizan C, Bhutta MF, Reed M, Lillywhite R. The carbon footprint of waste streams in a UK hospital. J Clean Prod. 2021;286:125446. doi:10.1016/j.jclepro.2020.125446

6. Kane GM, Bakker CA, Balkenende AR. Towards design strategies for circular medical products. Resour Conserv Recycl. 2018;135:38-47. doi:10.1016/j.resconrec.2017.07.030

7. Haas W, Krausmann F, Wiedenhofer D, Lauk C, Mayer A. Spaceship earth's odyssey to a circular economy - A century long perspective. Resour Conserv Recycl. 2020;163:105076. doi:10.1016/j.resconrec.2020.105076

8. Calderon Marquez AJ, Rutkowski EW. Waste management drivers towards a circular economy in the global south - the Colombian case. Waste Manag. 2020;110:53-65. doi:10.1016/j.wasman.2020.05.016

9. Bocken NMP, de Pauw I, Bakker C, van der Grinten B. Product design and business model strategies for a circular economy. J Ind Prod Eng. 2016;33(5):308-320. doi:10.1080/21681015.2016.1172124

10. Rhodes CJ. Endangered elements, critical raw materials and conflict minerals. Sci Prog. 2019;102(4):304-350. doi:10.1177/0036850419884873

11. MacNeill AJ, Lillywhite R, Brown CJ. The impact of surgery on global climate: a carbon footprinting study of operating theatres in three health systems. Lancet Planet Health. 2017;1(9):e381-e388. doi:10.1016/S2542-5196(17)30162-6

12. Wyssusek KH, Keys MT, van Zundert AAJ. Operating room greening initiatives - the old, the new, and the way forward: a narrative review. Waste Manag Res. 2019;37(1):3-19. doi:10.1177/0734242X18793937

13. Greenhealth P. Greening the OR; 2021.

14. Wormer BA, Augenstein VA, Carpenter CL, et al. The green operating room: simple changes to reduce cost and our carbon footprint. $\mathrm{Am}$ Surg. 2013;79(7):666-671. doi:10.1177/000313481307900708

15. Zygourakis CC, Yoon S, Valencia V, et al. Operating room waste: disposable supply utilization in neurosurgical procedures. J Neurosurg. 2017;126(2):620-625. doi:10.3171/2016.2.Jns152442

16. McGain F, Naylor C. Environmental sustainability in hospitals A systematic review and research agenda. J Health Serv Res Policy. 2014;19(4):245-252. doi:10.1177/1355819614534836

17. MacNeill AJ, Hopf H, Khanuja A, et al. Transforming the medical device industry: road map to a circular economy. Health Aff. 2020;39 (12):2088-2097. doi:10.1377/hlthaff.2020.01118

18. Rawlins L, Johnson BH, Johnston SS, et al. Comparative effectiveness assessment of two powered surgical stapling platforms in laparoscopic sleeve gastrectomy: a retrospective matched study. Med Devices (Auckl). 2020;13:195-204. doi:10.2147/MDER. S256237 
19. Ritthoff M, Rohn H, Liedtke C. MIPS berechnen: ressourcenproduktivität von Produkten und Dienstleistungen. [Calculating MIPS: Resource Productivity of Products and Services]. Wuppertal Institut für Klima, Umwelt, Energie GmbH im Wissenschaftszentrum Nordrhein-Westfalen; 2002.

20. Saurat M, Ritthoff M. Calculating MIPS 2.0. Resources. 2013;2 (4):581-607. doi:10.3390/resources2040581

21. Wagner B, Enzler S. Material Flow Management: Improving Cost Efficiency and Environmental Performance. Sustainability and innovation. Physica-Verlag HD; 2006:XI, 206.

22. Hauschild MZ, Rosenbaum RK, Olsen SI. Life Cycle Assessment. Theory and Practice. Vol. XX. Cham: Springer; 2018:1216.

23. NHS England. Data from: National cost collection: national schedule of NHS costs - year 2018-19 - NHS trust and NHS foundation trusts; 20182019.

24. Improvement NEaN. Delivering a 'Net zero' national health service; 2020:PAR133.
25. Royal College of Nursing. Freedom of information follow up report on management of waste in the NHS. Policy and Position Statements; 2018.

26. U.S. Food \& Drug Administration. Submission and Review of Sterility Information in Premarket Notification (510(k)) Submissions for Devices Labeled as Sterile, Guidance for Industry and Food and Drug Administration Staff, Docket Number: FDA2008-D-0611, Center for Devices and Radiological Health and Center for Biologics Evaluation and Research (2016).

27. Leiden A, Cerdas F, Noriega D, Beyerlein J, Herrmann C. Life cycle assessment of a disposable and a reusable surgery instrument set for spinal fusion surgeries. Resour Conserv Recycl. 2020;156:104704. doi:10.1016/j.resconrec.2020.104704

28. Medtronic. R2146-1018 signia $^{\mathrm{TM}}$ stapling system useful life; 2021.

29. Medtronic. Signia ${ }^{\mathrm{TM}}$ stapling system in-service guide; 2020.
Risk Management and Healthcare Policy

\section{Publish your work in this journal}

Risk Management and Healthcare Policy is an international, peerreviewed, open access journal focusing on all aspects of public health, policy, and preventative measures to promote good health and improve morbidity and mortality in the population. The journal welcomes submitted papers covering original research, basic science, clinical \& epidemiological studies, reviews and evaluations,

\section{Dovepress}

guidelines, expert opinion and commentary, case reports and extended reports. The manuscript management system is completely online and includes a very quick and fair peer-review system, which is all easy to use. Visit http://www.dovepress.com/testimonials.php to read real quotes from published authors. 